\section{SOFT POWER ARCHITECTURE: (UN)INTENTIONAL AND INCIDENTAL IN CULTURE RELATIONS POLICIES}

JАПАНСКА SOFT POWЕR АРХИТЕКТУРА: (НЕ)НАМЕРНО И НЕОЧЕКИВАНО У ПОЛИТИЦИ КУЛТУРНЕ РАЗМЕНЕ

Оригиналан научни рад, рад примљен: септембар 2019., рад прихваћен: децембар 2019.

Ivan Filipovic*, Dragana Vasiljević Tomic **

\section{ABSTRACT}

States' cultural policies for international relations take various forms, both intangible and tangible. This paper will focus on the latter, namely, exported architectural manifestation utilized as cultural negotiation tools. In this research, exported architecture is considered to be any built (realized) spatial manifestations, non-native to the county in which it is placed. Subsequently, architecture is viewed and examined as a cultural resource, having the power to influence bilateral relations presenting a new term, 'soft power architecture' as conceived, exported, and state-controlled spatial manifestation, with a clear set of goals inscribed within cultural relations policies. The notion of architecture-as-a-negotiating-instrument between various actors is introduced, borrowing from Joseph S. Nye's definition of the term "soft power" postulated as, in the most basic terms, as the ability to attract, with attraction often leading to acquiescence.These typologies have a profound impact and yet the policy makers remain unaware of the importance of architectural manifestations as cultural resources. Requirements of the re-conceptualization of the state's policies regarding the planning, implementation and management processes for diplomatic-consular outpost will be discussed. Lastly, the case study of the new Japanese embassy in Belgrade, Serbia, will be examined, noting particularities of its processes, arguing an unintentional paradigmatic shift, providing a theoretical and methodological framework for future research.

Key words: cultural relations policy, soft power architecture, embassy, identity, nation branding

* Ivan Filipović, PhD candidate, Faculty of Science and Technology, Keio University (Japan), Department of System Design Engineering, ivan.filipovic@keio.jp Иван Филиповић (1987), докторанд, Факултет науке и технологије, Кеио Универзитет (Јапан), Департман системског инжењерског пројектовања, ivan.filipovic@keio.jp

** dr Dragana Vasiljević Tomić (1964), Associate Professor, Faculty of Architecture, University of Belgrade, Department for Architecture, draganavt@arh.bg.ac.rs др Драгана Васиљевић Томић (1964), ванредни професор, Архитектонски факултет, Универзитет у Београду, Департмант за Архитектуру, draganavt@arh.bg.ac.rs

\section{АПСТРАКТ}

Међународни односии пратећестратегије културнеразмене могупопримати различитеоблике, каконематеријалне, тако и опипљиве. Овај рад ће се фокусирати на другу категорију, наиме, извезене архитектонске манифестације које се могу користити као оруђе у политици културне размене. У овом истраживању, за извезену архитектуру сматра се било која изграђена (реализована) просторна манифестација, која потекла из окружења у којем је смештена. Архитектура ће бити посматрана и испитивана као културни ресурс, који има моћ утицаја на билатералне односе, представљајући нови термин, "Soft Power архитектура“ који подразумева пројектовану, извезену и државно-контролисану просторну манифестацију, са јасним циљевима који одражавају тежње политике културне размене. Уводи се и појам архитектуре као инструмента преговарања између различитих актера, интерпретирајући дефиницију појма „soft power“

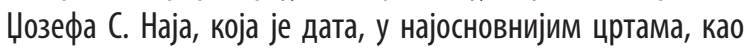
способности привлачења, са привлачношћу која често води ка прихватању ставова друге стране. Ове типологије могу имати снажан утицај по више основа, првенствено на просторну интеракцију и националну репутацију, међутим, креатори политике и стратегија остају несвесни важности раније поменутих архитектонских манифестација као културних ресурса. Чланак ће поставити теоретске оквире неопходности ре-концептуализације државних политика у погледу процеса планирања, спровођења и управљања дипломатско-конзуларним испоставама. Такође, проучавањем студије случаја нове јапанске амбасаде у Београду, примећује се специфичност њених управљачких процеса као и новонасталих просторних последица, стварајући парадигматични помак, описујући теоријски и методолошки оквир за будућа истраживања.

Кључне речи: политика културне размене, soft power архитектура, амбасада, идентитет, националнобрендирање

\section{INTRODUCTION}

This paper seeks to explore and elaborate upon the causative correlation between culture relation policies and architecture. The presented research argues that exported architecture is an underused cultural resource. In the context of this research, 
exported architecture is considered to be any built (realized) spatial manifestations, non-native to the county in which it is placed. Exported architectures have the potential of influencing the study of international relations (IR) and ought to be defined by cultural relations policies (CRP). Namely, it investigates the concept of soft power architecture, as a way to associate various scholastic researches on IR, cultural relations policies, architecture and urban planning.

Tentatively dubbed soft power architecture [SPA] concept is presented and expounded upon, exploring its potential and power in shaping bilateral relations, providing tangible indicators of its dynamics. Borrowing from Nye's (2004) term of "soft power", the author suggests another component, introducing the notion of architecture-as-a-negotiatinginstrument between various actors. Joseph S. Nye defined the term "soft power", in the most basic terms, as the ability to attract, with attraction often leading to acquiescence. This is achieved by utilizing "soft" initiatives as cultural and intellectual exchange, as opposed to "hard" power, defining the country's military or political influence in the global arena. (ibid.)

As defined in this research, SPA constitutes any exported architectural typology, permanently planned, utilized as a communication tool, fostering mutually beneficial bilateral relations and producing positive spatial effects. The text differentiates between the producers and consumers of said architecture, the country of origin (the sending state) and the receiving (alternatively: host) country, accepting its architectural manifestations. Soft power architecture, if utilized as a communication tool, can inform aspects of international relations for both the sending and host countries and be used as a unique benchmark for examining bilateral processes.

Different state and non-state actors employ various stratagems to communicate their ideological processes. Their outcomes have intangible and/or tangible manifestations: for SPA, these ideologies can be mapped, examined and quantified. It is argued that, in order to grasp these processes and their outcomes, one must be made aware of mechanism, manifestations and spatial consequences of exported architectures. Mechanisms are the forces that shape CRPs, manifestations are its physical representation and spatial consequences are a complex, multilayered, dynamic spatial interrelation of soft power architecture and urban matrices of host countries.

Arguably, unfavourable characteristics and by-products of this interplay can be mitigated, with careful conception, planning, implementation and management of pertinent cultural relation policies. The presented findings question the awareness of policymakers and researchers of international relations, arguing the lack of related data can prove detrimental to longterm bilateral relations development.

International relations research focusing on architecture is usually done after-the-fact: any considerations on spatial consequences do not factor into the decision making process for cultural relations policies. On the other hand, architectural research on exported typologies utilized as a communicative tool primarily focuses on the conceptual stages and its outcome, not examining the spatial aftermath, ensuing changes in urban matrices and their wider implications on the cities, policies and bilateral relations.

A nation of complex and multifaceted international relations through its history, Japan has been chosen as an example of a country that has accidentally triggered a paradigmatic shift in approach to international relations research. Japan has been also chosen due to the fact of its recent heavier investment in public diplomacy; however, its cultural relation policies remain questionable, vis-à-vis soft power architecture. Even without any visible masterplan of utilizing SPA as a cultural resource in its policies, Japan produces (un)intentional effects of the placemaking processes for its exported architectures.

Furthermore, this paper argues such impact occurred during the construction process of the new Japanese embassy in Belgrade, the Republic of Serbia (May 2013-March 2015). Japan, a country of interesting bilateral relations history with Serbia, initially failed to achieve full potential of its new embassy building, temporarily damaging its reputation. Arguing that these negative effects could have been avoided and/or mitigated, this paper draws attention and proposes a re-examination of current policies, stating spatial consequences as a trigger for lessening Japan's standing.

Lastly, the general suggestion for research, based on presented observations, will be given, arguing that the topic will gain importance in the future. Objectively, there are no clear-cut conclusions or interpretations of diplomacy efforts and its effects on architectural representation in today's global arena. It remains, however, a point of interest, with potential for further research, as the international relations research and the practice of architecture are constantly shifting: interdisciplinary research and multi-layered study of international relations, cultural policies, and architecture may provide the answers.

\section{CO-CONSTRUCTION OF MEANINGS AND RESEARCH HYPOTHESIS}

Why are exported architectural typologies relevant for cultural policies research? The answer is straightforward: these architectural and spatial manifestations are a tangible expression of cultural relation policies in foreign countries. While these policies may start as intangible, they will gain materiality that will inadvertently influence the actors and spatial dynamic in host countries. In other words, policies will become conceived, perceived and lived experiences, a reality for peoples of host countries. As such, all actors involved bear a shared responsibility to their respective constituents to make the optimum choices, bearing in mind the far-reaching effects of soft power architecture.

Moreover, referring to the theory of constructivism in international relations, its hypothetical proposition claims that neither objects nor concepts have any necessary, fixed or objective meaning; rather, their meanings are constructed (coconstructed) through social interaction (Mingst, 2014, p.95). 
As this interaction is crucial for understanding other cultures, people and customs one must make an effort to make incentives that would further help this cause. Nowadays, manipulation of information is regularly applied and arguably, we live in a world of post-truth and post-truth politics (word of the year 2016, as declared by the 0xford Dictionary). Post-truth (alternatively: post-factual) politics is a culture in which debate is framed largely by appeals to emotion disconnected from the details of policies, and by the repeated assertion of talking points to which factual rebuttals are ignored. Post-truth differs from traditional contesting and falsifying of truth by rendering it of 'secondary' importance.

The outstanding question is whether the policymakers have any concept on the importance of architectural representation and its impact on diplomacy efforts? It is necessary to establish cooperation between different actors to maximize the potential that architectural representation can bring. The subject of architectural identities and representation on foreign soil is not new; namely, these questions arose with exported architectures. Additionally, architects and/or designers are obliged to create primarily safe spaces, not necessarily project the desired/expected image of a country. Furthermore, the issue of identities became increasingly polarizing in the age of globalization. Until recently, the embassy design brief was simple: provide safety and conspicuousness. This is especially true for Western colonial forces, using architecture as a form of propaganda, ascertaining and validating their power. Spatial projections are thus utilized for required effects.

The research propositions/hypothesis are:

- Official governing bodies possess limited awareness of the possible affirmative effect that soft power architecture can ensue and/or consciously choose to disregard its potential, either under the guise of ensuring the safety of its constituents abroad or through various justifications (political, economic, diplomatic...etc.), with positive effect generators sought elsewhere;

- Official governing bodies possess a vague perception of needed investment into soft power architecture with accompanying functions and content it provides. Even if such awareness exists, the lack of interdepartmental sync of governmental offices and absence of long-term strategies hinder these goals (implied by Kawamura, 2018b);

- Spatial consequences of thus formed spaces, if not carefully managed throughout their conception, implementation and monitoring process [lifespan], produce effects adverse to the original concepts and intentions (if there were any to begin with), being harmful to bilateral relations, having tangible and measurable manifestations in urban city matrixes.

The proposed hypotheses will be additionally discussed, after the presentation and analysis of pertinent data and case study of the realization process for the new Japanese embassy in Belgrade, Serbia. The gained insight will, in all probability, open different research avenues and draw importance to this increasingly pertinent topic.

\section{CULTURAL RELATIONS POLICIES AND ARCHITECTURE}

This section will build upon the selected works of Kawamura $(2016,2018 a, 2018 b)$ to draw attention for the long-overdue reconceptualization of management for exported architectures utilized as a cultural negotiating tool. While discussing cultural relations policy, referring to the state's strategies employing cultural tools, these resources mostly remain in the sphere of intangible and/or temporal activities.

To further understand the proposed bilateral relation, in the context of this research, the terms of sending and receiving state will be defined, expanding Berridge's (2015) classification:

Sending state - state of origin for any architectural and nonarchitectural manifestations that are specifically formulated, manufactured and promoted with the sole purpose of export and/or achieving a specific set of goals outside of the sending states' borders.

Receiving state - state that acts as a host for any architectural and non-architectural manifestation of the sending state, ostensibly granting special privilege e.g. preferential treatment, land management or favourable media coverage (either obligatory or individually motivated), with presupposition that the receiving state operates within its own set of ideological, architectural and spatial rules and processes.

As architecture can be considered a spatial manifestation of prevailing ideology and sets of goals to be achieved (or lack thereof), newly produced spaces of intended cultural negotiation can serve as an indicative benchmark for examining the sending state's intent (Ignjatović, 2007). Adding another layer of validity, spaces utilized for diplomatic and adjoining activities of diplomatic-consular outposts are solely controlled by the sending state's government, so management of these cultural resources lies solely within the purview of the elected officials.

To examine the supposition that soft power architectures can be viewed as cultural resources: as spatial manifestations placed in foreign environments they will inadvertently produce measurable (spatial) effects in cities, on general public's opinion (based on the building process, its appearance as well as the media coverage), ultimately reflecting on bilateral relations between nations.

Kawamura makes attempts to develop a comprehensive theoretical framework for cultural relations policies, referring to them as: 'state's policy that aims to build better intercultural relations utilizing cultural tools or resources.' (Kawamura, 2018a) This paper reinterprets the framework set by Kawamura, adding one point of interest that ought to be included in CRPs: soft power architecture i.e. any state-sponsored exported spatial manifestation, specifically constructed with intentions of improving cultural relations between nations.

Architecture can be viewed and examined as a cultural tool subsequently having the power to influence the relations 
between countries'. It can also communicate certain values and/ or ideas and serve a tool for culture negotiation. Throughout history, exported architectures have had many incarnations, from malevolent conception, rejecting the idea/culture of dialogue, consideration and cultural sensitivity, to benevolent intent, with typologies used to establish and promote mutual understanding between nations.

Exported architecture utilized as a communication tool is a neutral, appropriate term that subsumes both malevolent and benevolent types of architecture. Be it architecture with detrimental effects on cities, its inhabitants and bilateral relations, as in a show of supremacy or the one for strengthening bilateral ties, both types endeavour to communicate particular messages.

Regarding the exported architecture, the following questions arise: Why is the importance placed on exported typologies? and Is it important who implements the export process (who is the instigator of such export) and who is expected to profit from it?

The main difference when referring to other academic works dealing with architecture as a tool for the construction ofidentity, ideological representation, and ideological confirmation is that such projects are usually set in a pre-established context of society and/or architecture. Furthermore, the considered effects can be placed in a finite number of scenarios, or considerably less compared to the exported architectural typologies, due to the dynamic nature of implementation and control for these processes.

With soft power architecture, however, interpretative stratagems can act and evolve differently within a distinctive context and produce diverse consequences and meanings, not necessarily in sync with original intentions, as it happens for the export of architecture/ideology. One must underline that these 'transmutation' effects are applicable for both malevolent and benevolent projected types of exported architecture, e.g. colonial architecture, depicting power and supremacy of the sending state and soft power architecture, representing the willingness for deepening mutual understanding between countries. An exceedingly important point to be made is that the policies ought to be flexible in the sense of anticipating changes to happen and, if need be, to carefully monitor them, not immediately nipping them in the bud.

For this paper, the focus will be on the exported architecture that, in its conception, implementation and spatial consequences stages had the benevolent projections and conceptualization, as the mechanisms that govern these processes are deemed to be more complex when compared to the malevolent projections.

It is necessary to note the awareness that spatial consequences for any type of exported architecture conceptualization (desired malevolent or benevolent projections) can have either beneficial

1 UNESCO's Cultural Soft Power Info Sheet:http://www.unesco.org/culture/ culture-sector-knowledge-management-tools/11_Info\%20Sheet_Soft $\% 20$ Power.pdf or adverse effects in the urban city matrixes, unrelated to its original intentions. This is especially important for the introduction of the time component, as it plays a crucial role in defining and implementing the type of exported architecture of the sending state.

As for the second research question, when it comes to the question of who implements the export process (who is the instigator of such export) and who is expected to profit from it, the answer is not clear-cut, especially for the latter. Although the network of actors in international cultural relations is extensive and cannot (and should not) be segmented, in the context of this research, this paper will explore the state actors i.e. the official governing bodies and their policies.

The analogy of producers and consumers of exported cultural resources, postulated by Kosaku Yoshino (1992) may be correspondingly implemented as a theoretical postulate in this research. The question officials presumably pose, when conceiving their cultural relation policies and strategies, would be - whom are they intended for? Continuing in a similar vein, when pondering the questions of soft power architecture, another layer of complexity must be added: reproducing the established architectural and urban patterns of the host country, having a simple footing in the desire to maximize the gains. To do so, to reach as many consumers as possible, utilizing soft power architecture, the producers of the said architecture ought to be aware of the intricacies required to achieve their goals. Granted, when dealing with intangible and unknown factors of a newly established category of soft power architecture, it usually does not bode well for result-oriented bureaucrats, but hopefully, saner heads will prevail. The main purpose of this research is to introduce the importance and pertinence of the topic, then through its development, onsite trial-and-error phases, gain deeper insight and formulate optimum, sustainable strategies.

The aims of official governments are, by default, multifaceted, but for this paper, we shall focus on policies with the end goal of establishing mutually beneficial bilateral relations. When it comes to soft power architecture, however, it is evident that the officials possess limited knowledge of these pertinent issues, since the knowledge base is currently insufficient.

Another important point that ought to be made about these specific typologies is they can serve as facilitators of international cultural relations, highlighting the multidimensionality of culture and cultural sensitivity between actors.

Chosen spatial manifestations of cultural relation policies that will be examined will be in the sphere of soft power architecture, i.e. spatial cultural resources to create ostensibly positive effects in international cultural relations. The authors have chosen to italicize the word 'ostensibly' as the main questions remain whether the cultural policy researchers, legislators, and professionals are aware of the impact that soft power architecture may have within the arena of international relations, as will be demonstrated in the case study. 
Kawamura defines Cultural Relation Policies as:

... a policy or activity by the state of managing, maintaining and developing icr [international cultural relations] involving different actors, and has been called by various terms, such as international cultural policy, cultural diplomacy, public diplomacy, international cultural exchange, etc. (Kawamura, 2018a, p.2).

Reviewing this definition, soft power architecture has the greatest impact not only in 'external' cultural policy (exemplified by traditional cultural or public diplomacy) but also in broader 'outward' cultural policy or nation branding (ibid). However, the effects of soft power architecture can also be felt (and amplified by policies) in 'inbound' and 'inland' cultural policies i.e. embassies and/or cultural centres as places that will attract future visitations to the sending country, as well as facilitating intercultural education and diversity management.

It is necessary to underline the importance of processes as an extension of policies (see: Figure 1): while the 'end product' will not always live up to its potential and/or expectations, there is value to be observed in the process, as an epitome of cultural relations policies. In this particular facet, the communicative practice and transparency in addressing e.g. the general public of the host country are crucial in mitigating any expected negative effects, as will be discussed in the case study of the new Japanese embassy in Belgrade, Serbia.

In the context of this particular research, special attention is given to the notion of process(es), specifically, the realization process, as it is deemed as one of the crucial means to achieve a particular, desirable end. It is worthy to note that, to achieve a specific soft power outcome, the means cannot remain static, but rather, must be flexible and shift alongside the circumstance to compensate for any discrepancies that arose during the period necessary to achieve the ends. A moving target metaphor, both in approach and handling the changing situation(s) is apt for this assessment.

In this sense, previously defined building lifespan and monitoring processes (before and after building completion) stand out as the most obvious means, often disregarded, with the hypothesis that, if enough consideration is to be given to these aspects, ends can be achieved more effectively, lessening undesirable spatial consequences.

This section will offer a methodology for researching cultural relation policies, its conceptualization, implementation, management and monitoring of soft power architecture, in this particular case, embassy buildings. Every given aspect of stages for soft power architecture can be researched individually, from different perspectives (global and local perspectives, bilateral relations, international relations policies, cultural exchange ... etc.).

Transnational movements (international relations at a societal level, private activities of international exchange, fostered by SPA); International governmental policies (orthodox international relations); External governmental public relations/PR (traditional public diplomacy; a state's approach to the other states, in order to create favourable public opinions).

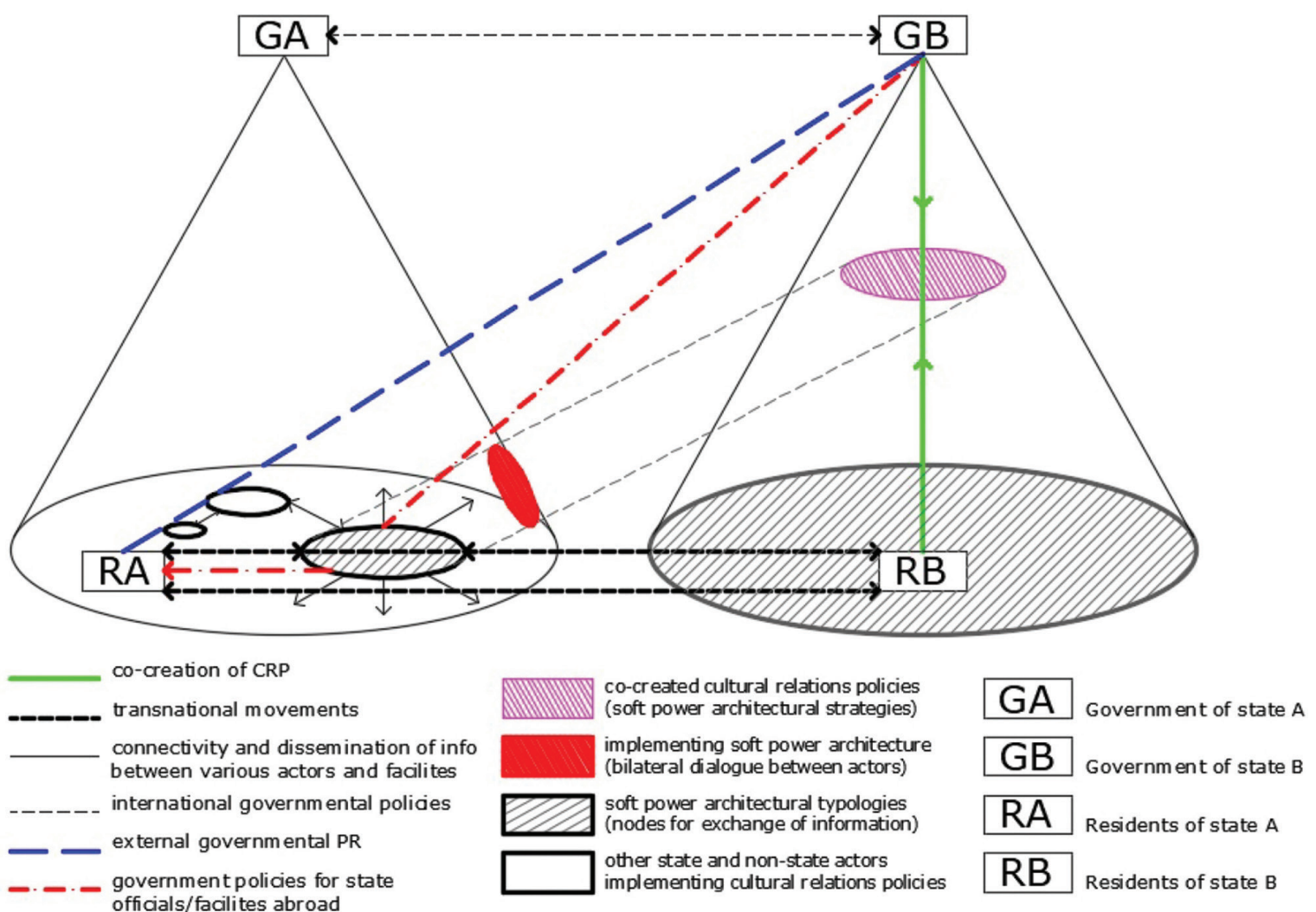




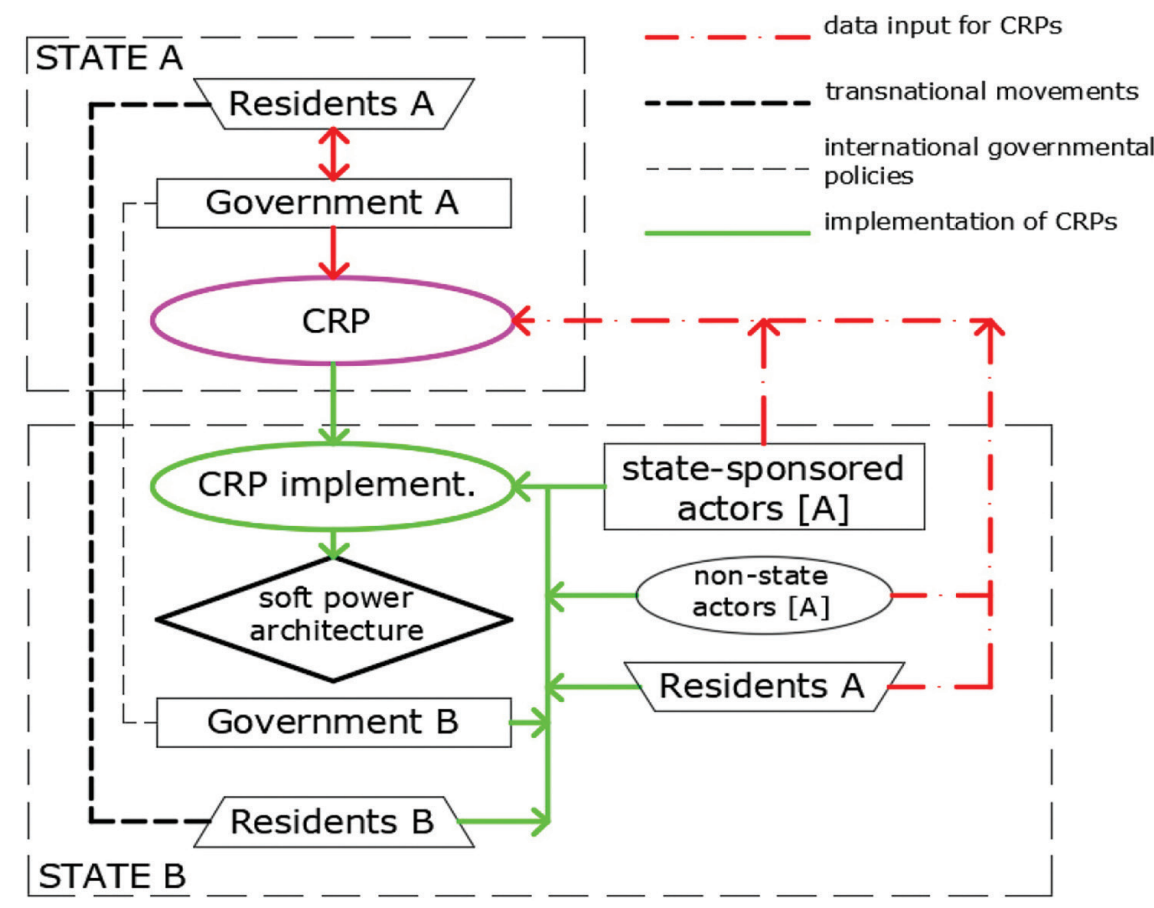

Fig. 2. Preparation and data gathering processes for formulation of soft power architecture CRPs

Сл. 2. Припрема и сакупљање података неопходних за формулацију политике културне размене за soft power архитектуру
If we try to follow the process of implementation of cultural relation policies (see: Figure 2.) the process goes as follows:

1. CRP for soft power architecture creation: Cultural relation policies are co-created by the State B, utilizing a network of state and non-state actors (Residents of State B and Residents $B$ living in State A), to foster good bilateral relations with the State $A$.

In architectural terms, the chosen location for the new soft power architecture, its spatial context, activities, and specificities must inform the policies. Architecture and urban planning professionals from State $B$ are encouraged to make a preliminary report/feasibility study for the location in State A. As architecture for different spatial dispositions is highly contextual, apart from some general policies and guidelines, it is highly suggested these reports be made for every new development (e.g. in States C, D, E . . . etc.)

2. Preparation for implementing soft power architecture: The most important segment in cultural relations policies aimed at architecture. Bilateral dialogue between Governments, State and non-State Actors of both countries is encouraged. The emphasis is placed on implementing the local know-how and the contextual nature of the construction process. Some recommendations may clash with the official CRP and/or governmental policies of both states, so compromise is proposed, due to the sizable impact of the new development, as well as the far-reaching consequences (spatial, reflecting on bilateral relations) this architecture can produce.

3. Implementation of soft power architecture: Local experts are employed to ensure smooth development and completion of the project. The general public of the host country [State A] is introduced to the project, through various means (public debate on the new constriction, media outlets, official statements from the sending country ... etc.) It is imperative to manage expectations and control the official narrative of the new constriction process. This is why close communication between all state actors of the sending country [State B] (both in sending and receiving countries) is required.

4. Management and monitoring of soft power architecture: After successful implementation stage, the sending state [State B] ought to continue to be involved with activities, communicating closely with state and non-state actors of the host country [State A], as well its residents [Residents $B]$ in State A. As the contextual nature of every environment was previously stressed, it is recommended that cultural exchange experts be employed by the embassy to create and implement the program best suited for the host country. Furthermore, the assumption being (if CRP successfully and fully implemented), that the embassy will become a node for other state $[B]$ actors in the host country [State A], as well as for Residents $A$ and other actors of State A.

\section{IDEOLOGY AND EXPORTED ARCHITECTURE}

In his work, Mayo (1996) suggests that, by their nature, political ends are future-oriented, but to accomplish them, the means must precede the ends. In this sense, a differentiation ought to be made regarding the positioning in the future timelines: some goals are set in the near, other in the distant future. With soft power, the goals are set in the distant future, which, in terms of political motivation, will greatly influence the shaping of means to reach these particular ends. 
Manuel Castells (1977) argues that ideologies have a causal effect on the cultural forms (including architecture) that societies produce. Castells also notes that the expression of ideology in cultural form recognizes and legitimizes it (ibid.). The implication he makes is clear: the political means-end relationship between politics and cultural forms. A similar thought was articulated by Ignjatović (2007) stating that:.... architecture does not capture, but rather constructs and legitimizes every societal reality and ideology.' In both instances ideology uses different means to achieve its ends i.e. utilizing architecture or cultural forms to construct, legitimize or reinforce its standing.

Another scholar famous for his progressive thinking and the term the right to the city, Henri Lefebvre, makes an important point in claiming that political control directly affects what form the designed [architectural] space will take. When discussing this issue, in the context of this research, one cannot go without adding another layer of dual political controls, or rather duplication, two sets of everything: ideologies, processes, forms, formats. In this sense, it is extremely pertinent to view and consider all examined goings-on in the plural. Such duality and/or plurality can be directly applied to exported architecture i.e. for ideologies, processes, jurisdictions, obligations ... etc.

As defined by Mayo, both Castells and Lefebvre accept a meansends relationship between ideology and built form; they temper their views by accepting a contingent rather than an absolute relationship between the two (Mayo, 1996).

So, in practice, if urban regulations can change, the standing question is on the power of the professions within negotiations and preserving the best interest of the development of cities. Ostensibly, the governmental agencies were not used as a mere rubber stamp tools, the problem remaining - what sort of power did the official have, remembering the anecdotal saying that one negotiates from a position of strength. Other issues have arisen, most notably, the ban on photographing the premises (façade and exterior of the embassy), even if an individual is

Fig. 3. Interconnectivity and spatial consequences of soft power architecture (Fig.3a (left) - Inter connectivity, cooperation, output and engagement between various actors and policies; Fig.3b (right) - Spatial consequences and interaction of SPA onto/with the environments of host countries)

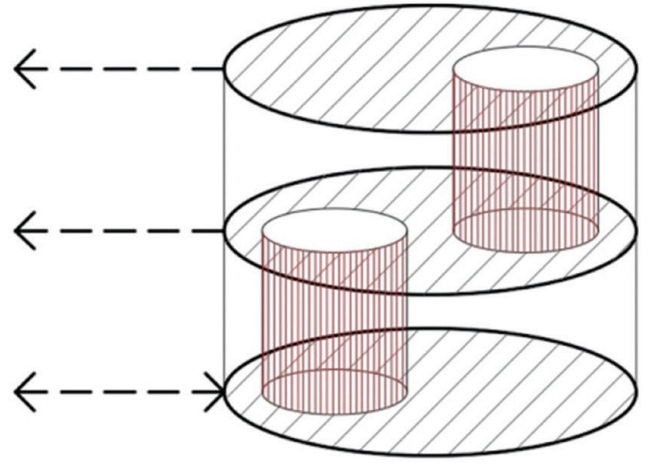

located within the public space. Such actions question the right to the city postulated by Lefebvre (Butler, 2014.) and generally have a deeper significance of abolishing freedom of movement of users of space, which is precisely why these typologies ought to be under scrutiny by the professional and official, from its inception, throughout its lifespan, to avoid misuse of power.

Akira Iriye, a Japanese diplomatic historian defined culture as 'structures of meaning,' including 'memory, ideology, emotions, lifestyles, scholarly and artistic works' (Iriye, 1997: 3) (author's annotation in bold). Production of 'structures of meaning', when institutionalized, is possible to follow, map and interpret in different manners. One fact remains constant; however, these structures depict prevailing ideologies that shape them and can serve as a slice of historical research of cultural policy enquiries. These layers can be overwhelmingly indicative when viewed in the context of soft power architecture, inadvertently exposing the multifaceted nature of processes and ideologies in place at the time of their constitution and implementation.

Previously defined exported architectures, with the added distinction of being state-sponsored and state-controlled, with all of the accompanying processes, form an informative database, especially for examining bilateral relations between sending and host countries. One of the interests for this research is, specifically, the spatial projection of society of the sending country, which is equally reflective for the host country. Shifting of power dynamics examined through time perspective, for architecture, can be enlightening when studying cultural relations policies, as one can argue that policies are a mechanism for ideological reproduction and exported architectures are their manifestations.

\section{DEFINING THE RESEARCH FRAMEWORK FOR SOFT POWER ARCHITECTURE}

Researching influence of international relations on cultural relation policies and subsequent spatial manifestations (soft power architecture) are proposed as follows: by utilizing

Сл. 3. Међусобна повезаност и просторне последице soft power архитектуре Сл..За Међусобна повезаност, сарадња, излазни подаци и ангажовање различитих актера; Сл.3b Просторне последице и утицај-интеракција soft power архитектуре на-са окружењем у земљи-домаћину

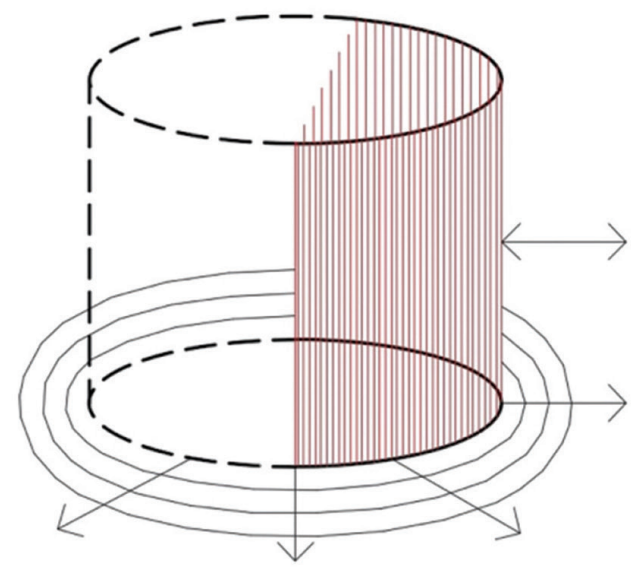



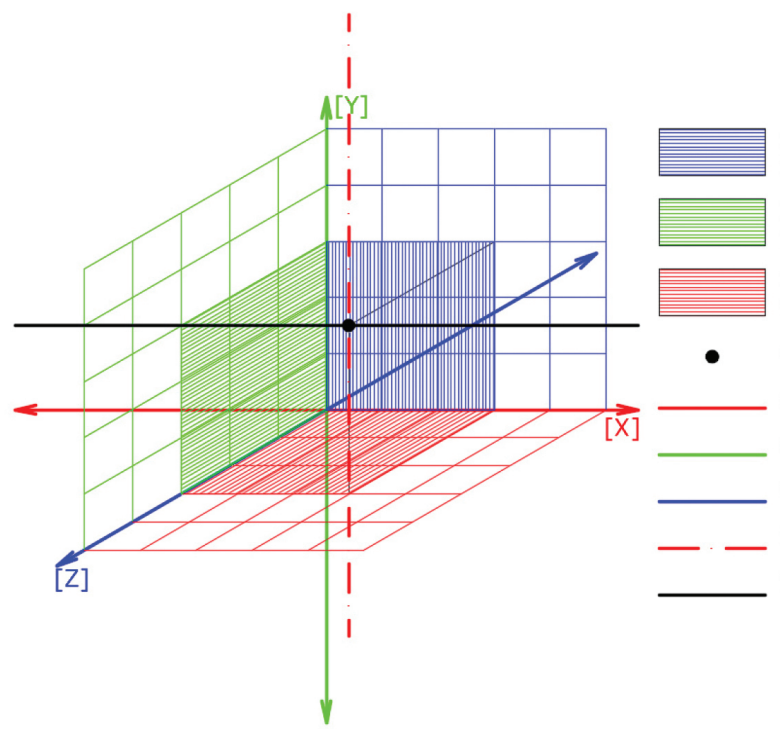

mapping/measuring changes in the time component

mapping/measuring changes of the spatial effects

mapping/measuring changes in

the designed lifespan

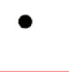

coordinates of desired case study

designed lifespan component [X]

spatial effect component $[\mathrm{Y}]$

time component [Z]

transformative quality

temporal quality

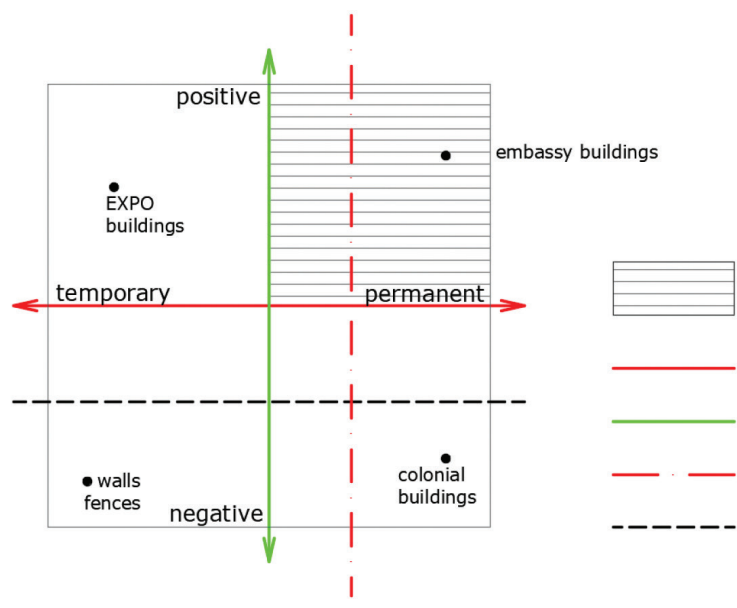

determinants (1) designed lifespan component; (2) spatial effect component and (3) time component, within a threedimensional Cartesian plane $(1=X ; 2=Y ; 3=Z)$, successful mapping of the desired processes can be achieved (see: Figure 4). It is also possible to use a two-dimensional projection of the $X-Y$ axis, excluding the time component [Z], but its inclusion is advised whenever possible, guaranteeing an additional layer of data validity, providing for sound conclusions and discussion.

To reiterate, soft power architecture, in the context of this research, is considered to be any state-sponsored work of architecture exported outside the borders of its country of origin, built purposefully, as a new object, from the ground up, with the purpose of enhancing the relations (on different levels and scales) between the sending and receiving states, with or without ulterior motives on one or both sides. Soft power architecture is viewed as architecture with a permanent component (designed lifespan) because of the measurability of its influence/impact of the spatial environment through time.

This newly defined type of architecture is recognized to be found within and described by two qualities: its permanent conception for designed lifespan component $[X]$ and its positive effect for spatial effect component [Y] (see: Figure 5). Its starting point can be found within different quadrants and its movement/ transformation/repurpose can be attributed to transformative
Fig. 4. Three-dimensional Cartesian plane diagram of transformative and temporal qualities of exported architectures (with time component Z)

Сл. 4. Тродимензионални дијаграм трансформативних и темпоралних карактеристика извезених архитектонских типологија (са временском компонентом Z) soft power architecture

designed lifespan component [X]

spatial effect component [Y]

transformative quality

temporal quality
Fig. 5. Diagram of

transformative and temporal qualities of exported architectures

Сл. 5. Дијаграм трансформативних и темпоралних

карактеристика извезених архитектонских типологија and temporal qualities (see: Figure 5). The end point, however, if discussing soft power architecture, as defined by this paper, will always be found within the previously mentioned positive components.

When discussing cultural relation policies, in the context of soft power architecture, coordinates [0-0-0] are the place of CRP conception, before implementation. Before formulating said CRPs, all the gathered data will be formulated; one can argue that the process of obtaining information(see: Figure 2) can be a policy in itself, but as pertinent as it is, it will not be the subject of this research.

Additionally, one can be curious about the indicators for measuring the change in time component/spatial effects/ designed lifespan. A flexible approach, best suited for particular research should be implemented for any investigation utilizing this methodology. Indicators for each category are varied and should be left to the researchers' discretion. A standing discussion and a valid point can be made about measuring certain processes and/or occurrences, what Radović (2015) refers by measuring the non-measurable. Unquestionably, not all aspects can be quantified, but certain facets can be extricated and utilized for one's research. For example, when exploring changes in the spatial effects, certain indicators can prove to be useful: urban flows, accessibility, security. .. etc. 
Furthermore, two additional points must be made, to differentiate between types of exported architecture utilized as a communication tools: 1 . transformative qualities of exported architecture and 2. temporal qualities of exported architecture.

Transformative qualities: When researching exported architectures, one must be aware that the nature of such typologies in changeable within the parameter of time. For example, previously built colonial architecture, with its symbolic connotations can be, in time, be integrated within the physical and mental landscapes, altering its identity (see: Figure 5). An example that can be made is the inclusion of the Former Daehwajo Office Building, in Incheon Port, west of Seoul (Japanese colonial architecture), to South Korea's list of cultural assets, by the Cultural Heritage Administration². Of course, such transformation implies that the sending country is no longer utilizing that particular piece of architecture as a communication tool, but rather, the host country has absorbed and repurposed it, inscribing other cultural and ideological patterns within the typology. Furthermore, new developments can change the image and physical environment of cities, e.g. construction of new embassy buildings that can:

- Have a positive (attractive) effect, with neighbouring communities viewing the newly planned typologies as a sign of increased prestige, leading to e.g. increased real estate values, the opening of new businesses, rebranding of neighbourhoods or

- Have a negative (repelling) effect, where due to particular bilateral relations or cultural patterns, the newly planned typologies are perceived as undesirable in some manner, so the opposite effect takes place, leading to a discontinuity in urban life patterns and having detrimental effects on cities.

A note ought to be made, regarding positive and negative effects, external influences e.g. (un)favourable media coverage, propaganda, geopolitical situation ... etc. can shape the overall perception and manipulate the perceived effects.

2 https://www.blouinartinfo.com/news/story/923306/japanese-colonial-erabuildings-named-korean-cultural-assets

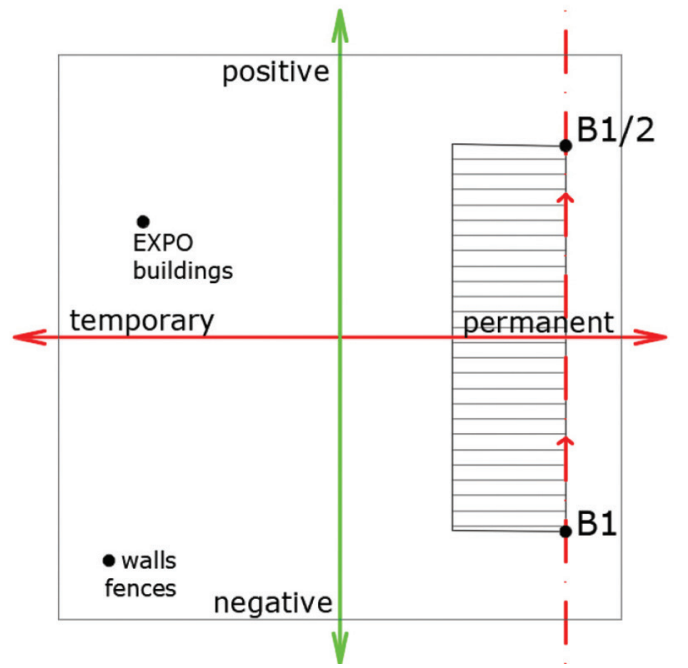

Temporal qualities of exported architectural typologies are equally significant; it is important to separate architecture utilized for communication of officially sanctioned images/ messages of national identity into two main categories i.e. planned and implemented to be: a. permanent typologies and b. temporary typologies.

- Permanent typologies can be considered to be any exported architectural typologies intended as a communication tool with the intention (of the producer) of permanent placement within the host country. These manifestations include but are not limited to: diplomatic-consular headquarters, diplomats' residences, cultural centres... etc. A significant point (in architectural terms, subsequently influencing the management processes and effects) ought to be made: within permanent typologies, there will be a differentiation between those (1) occupying already existing spaces and (2) newly constructed buildings.

- Temporary typologies are planned, implemented and managed with a limited lifespan in mind. The time factor can vary, from several weeks to several years, depending on the particular project. One point remains constant: all activities are planned to come to an end at some point in time. Examples can be found in e.g. exhibition pavilions, pop-up cultural centres, fair booths... etc.

A point was made about the nature of newly formed architectural typologies i.e. whether they occupy already existing or create new spaces. These two types will produce different effects, as the former will presumably not disturb the functional patterns of pre-existing frameworks with its inscription. The latter, however, will produce new relations with its environment, function, and activities and as such, must be carefully conceived, planned, implemented and managed. The overreaching goal for newly built SPA would be not to disturb the already established urban patterns in host countries and not to allow e.g. security concerns overflowing onto the public space.

Fig. 6. Transformative quality change diagram (time component as planar projection)

Сл. 6. Дијаграм трансформативне промене квалитета (поједностављен, временска компонента као планарна пројекција)

B1-B1/2 colonial bldg.-cultural heritage

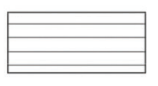
measuring transformative change designed lifespan component [X] spatial effect component [Y] transformative quality 


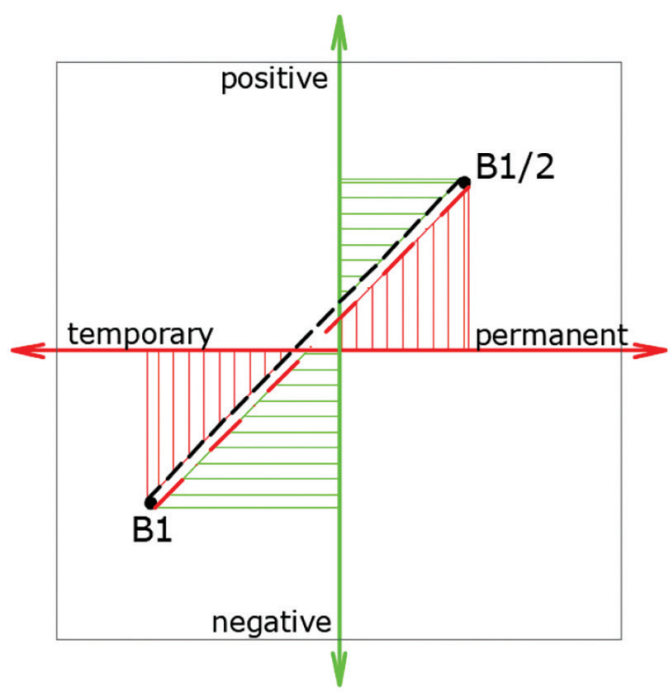

Going back to the transformative and temporal qualities, it is important to note that both are changeable within their respective categories, as well as cross-category (see: Figure 7). For example, when examining changeability within categories, certain spatial manifestations can initially have negative (repelling) effects, but if managed properly, they can change to possess positive (attractive) effects. Similarly, some temporary spatial manifestation, although initially planned for a limited amount of time, due to e.g. their success or through public engagement, can become a permanent fixture in host countries, if the sending country ascertains that such action would be beneficial vis-à-vis cultural relation policies. Alternatively, an example of cross-category changeability would be the transformation of temporary typologies, producing negative effects into permanent, producing positive effects. This change can be achieved with close bilateral cooperation and the will to promote cross-cultural understanding. Other cross-category changeability scenarios are possible but less probable.

\section{JAPANESE EMBASSY CONSTRUCTION PROCESS}

Every age in history has its trepidations; nowadays we live in a day and age of constant vigilance due to potential terrorist threats in cities. This trend is not new, but it gained significant expansion after $9 / 11$. Aside from the media that constantly inform on the dangers of everyday living, politics have great influence on the usage of fear, as it was proven that fear has best controlling potential in political discourse (Hristić Danilović, 2013.)

Embassies, by conceptual default, ought to serve as tools of communication and various facets of ideologies of the sending state (Vasiljević Tomić et al, 2013), with ambitions of establishing rapport and/or pre-determined goals to be achieved with the host country. As such, they often become tools for ideological reproduction, irrespective of the environment of integration. Ideology is one of the watchwords when it comes to understanding embassy typology, forces shaping it, or rather, forces that are utilized for ideological reproduction, as defined by Althusser (in Žižek, ed. 1994. p.130).
B1-B1/2 military barrack - war museum

measuring temporal change

measuring transformative change

designed lifespan component $[\mathrm{X}]$

spatial effect component $[\mathrm{Y}]$

transformative quality

temporal quality

Fig. 7. Transformative and temporal qualities change diagram (time component as planar projection)

Прилог 7. Дијаграм трансформативне и темпоралне промене квалитета (поједностављен, временска компонента као планарна пројекција)

Be it out of a desire to show respect to its host country of Serbia, to increase their already impressive soft power credit or due to long-term geopolitical strategy, Japan elected to implement a transparent construction procedure for its new diplomatic headquarters/embassy, located in Block 11a of New Belgrade.

In recent years, Japan has started to expand its foreign policy presence in the form of constructing new diplomatic-consular headquarters. For example, during fiscal 2015, then Foreign Minister Fumio Kishida and Finance Minister Taro Aso had agreed to open six new embassies and two consulates under the fiscal 2015 budget. The main motivation found in the statement: '. . . Japan is trying to enhance its diplomatic influence and better communicate its views overseas... in the year [2015] that marks 70 years since the end of World War II. ${ }^{3 \prime}$. It is important to note that the Foreign Ministry [of Japan] originally requested nine new embassies and six new consulates.

The embassy plot was acquired by the Japanese government in the 1990s, but owing to the breakup of Yugoslavia, the construction was postponed indefinitely. The entirety of Block 11a was, in its early, conceptual stages, designed to house various diplomatic missions and their corresponding residences (Blagojević, 2007). Due to speculative urbanism and land-use machinations, this particular place lost its original purpose, except for the Chinese embassy, until it was damaged and abandoned during NATO intervention in FR Yugoslavia in 1999.

After an extensive preparation period, the Japanese government green-lighted the new development, with construction starting in May 2013. Intended building procedure implementation was that of transparency, or to be more precise, the aspirations of implementing a transparent construction process. Design plans were re-worked to fit Serbian regulations (handled by 'Arhi.pro $\mathrm{LLC}^{\prime}$ in its inception stages ${ }^{4}$ ). Other Serbian companies were also involved, offering their expertise, both as professional supervision and as subcontractors ('Energoprojekt LLC' and 'Neimar V', respectively).

\footnotetext{
3 https://www.japantimes.co.jp/news/2015/01/12/national/politics-diplomacy/ ministers-give-ok-six-new-embassies-two-consulates-open/\#.XPTwWogzZPY
}

4 https://www.arhipro.com/en/references/design/embasy-of-japan 
Ultimately, through its many trials and tribulations, the new embassy building was completed and moved into during March 2015. Interestingly, response from the general public was negative, having predominantly commented on the aesthetic characteristics of the building (high perimeter fence, absence of openings, lacking in Japan-ness (Dale, 2011), linking these failings with feelings and/or relationship that the Japanese have in lieu of their perception of Serbia and its people. As a consequence, the most dominant questions arising was that of authorities that 'handed over' a 'prime piece of real estate' for such an 'architectural atrocity' ('Politika' printed article Urbanistički promašaj [Urban planning failure] by Mr. Branislav Jovin, March 3, 2015).

This sentiment, however crude in its phrasing raises a valid point: who has the authority to decide what is being built in cities and how does it influence their overall development? What about policies in place to deal with possible detrimental effects, do they even exist? Or will it be only researched after the fact, as Lefebvre put it, with architecture as a projection of society? As it happens, due to a multitude of aspects, input from the professional and local communities will have little sway, when it comes to deciding the future urban structure development, for examined typologies.

The power of governmental, city and civil-society organizations and the influence they should wield cannot be stressed enough. Granted, the construction of diplomatic offices is comparatively rare, but once the process has commenced, it reveals a lack of preparedness from the professional community to fight for cities and its users and development. There ought to be at least some general guidelines in place, which can be negotiable, in a dialogue between the representatives of the receiving and sending states, as a sign of goodwill and cooperation. Such guidelines may include e.g. volume of the building, façade materialization, access points and security (possible movement restrictions) ... etc.

An instance of possible exertion of the political influence of the sending country was apparent in 2007, when Belgrade's General Urban Plan [GUP 2021] was amended to fit the requirements of the new American embassy development. The legal remedy of this amendment, which was lawfully permissible, was found in the fact that the updates and amendments of the GUP can be done in phases. Other particularities were not disclosed in the given document ('Official Gazette of the City of Belgrade' Year $\mathrm{LI}$, number 34, dated October 17, 20075).

On the other hand, negotiations with sending states are not new, and it is possible to establish a true rapport if the architectural officials of the receiving states are determined to follow the previously set regulations, to ensure best urban developments for the cities. One such example was found in the construction process of the American embassy in the 1950s in The Hague, Netherlands (Loeffler, 2011, p.206) when the city official turned down the proposed plans, on the account of the building's lack of integration into the city matrix. Such an instance could have been expected, but it is surprising that it was not contested by the Americans, especially if one recalls the extraterritoriality clause (that was not invoked). So, ultimately, control of the city's developmental narrative can be achieved.

\footnotetext{
5 http://sllistbeograd.rs/pdf/2007/34-2007.pdf\#view=Fit\&page=1
}

Fig. 8. (upper) Japanese embassy plot, March 2011, @Sofija Burovac; Сл. 8. (горе) Парцела јапанске амбасаде, март 2011, @Sofija Burovac; Fig. 9. (down) Japanese embassy, image capture: May 2015, Google Maps, ○ 2019 Google; Сл. 9. (доле) Парцела јапанске амбасаде, мај 2015, Google Street View, @2019 Google (source / извор: https:// www.google.com/maps/@44.8249797,20.4190819,3a,82.1y,0.32h,98.75t/data=!3m6!1e1!3m4!1scxDVegaXrNZXv5ZnGfRntw!2e0!7i13312!8i6656)
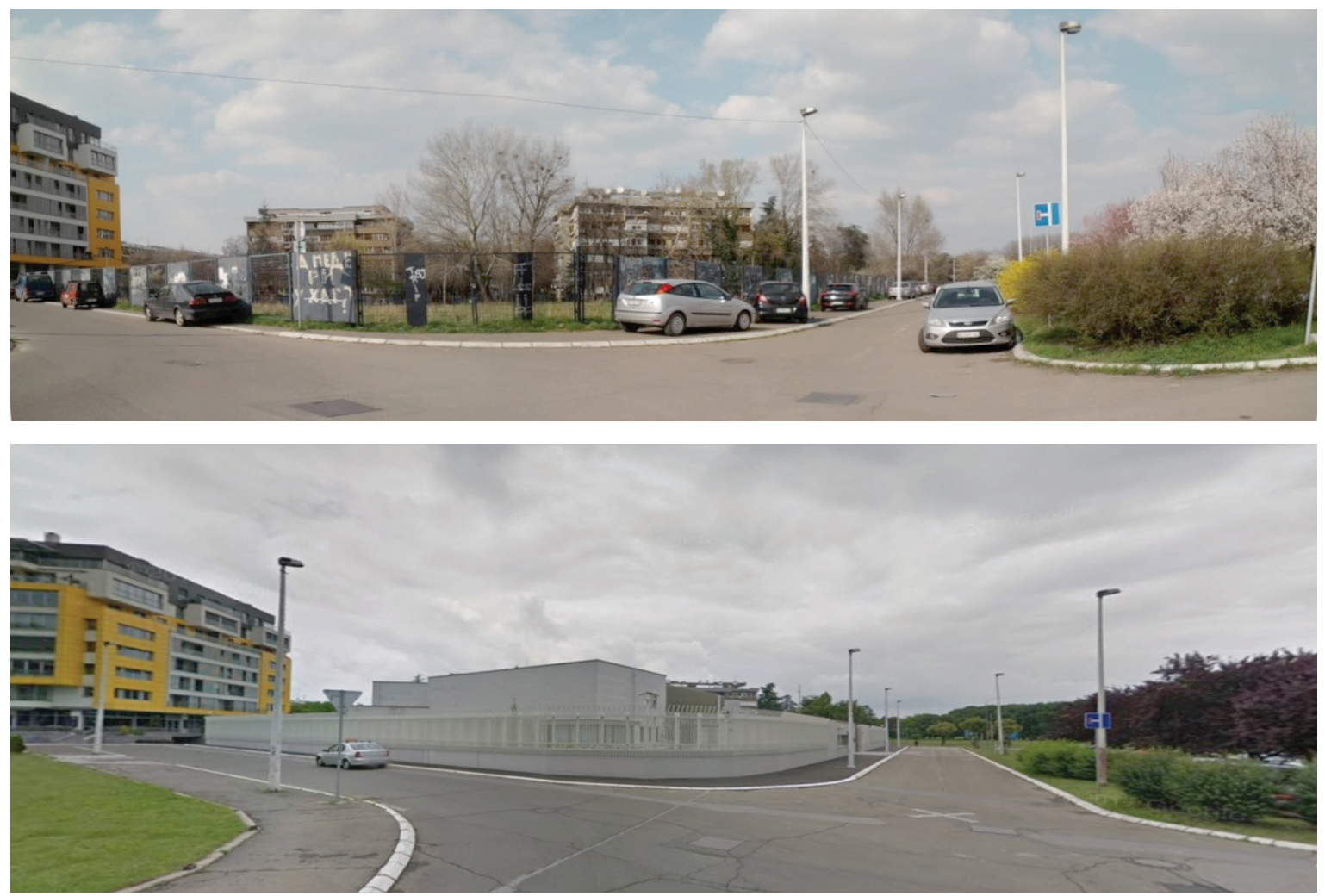


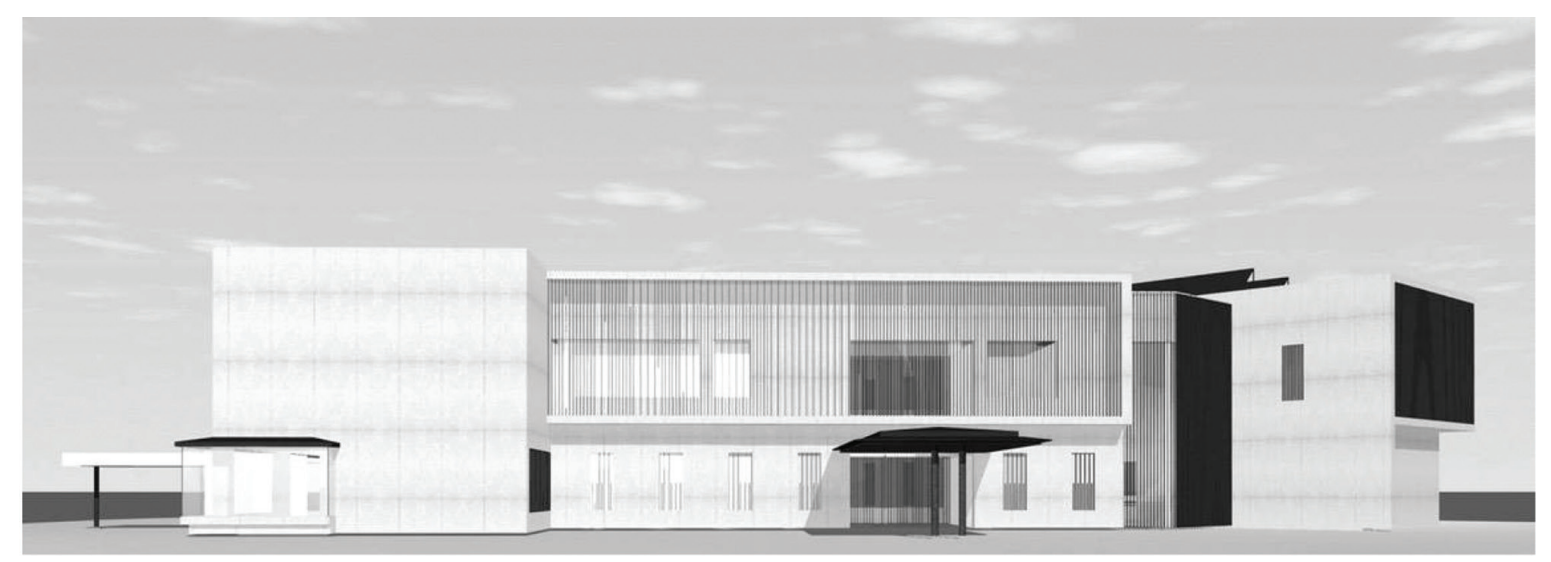

Fig. 10. The only available graphic representation of the new Japanese embassy in Belgrade during its construction (May 2013 - March 2015) @Arhi.pro;

Сл. 10. Једини доступни графички приказ нове јапанске амбасаде у Београду током њене изградње (мај 2013 - март 2015) @Arhi.pro (source / извор: https://www. arhipro.com/en/references/design/embasy-of-japan)

Other minor occurrences piqued the Serbian public's interest and reinforced the myths of Japanese uniqueness (Dale, 2011) e.g. morning calisthenics on the building site, removing one's shoes before entering the offices on-site, washing wheels of the construction machinery before exiting the building site onto the street. ..etc.

Another example of a (un)intentional soft power practice during the construction of the new Japanese embassy was the inclusion of architecture students in painting large-scale murals on the site's perimeter fence. Painting workshop was a two-day initiative in June 2013, the briefbeing to depict Japan-associated imagery. A competition followed, awarding monetary prize and books about Japan. This was an overwhelmingly affirmative activity, which can serve as an example of interconnection of different groups and increasing a country's soft power.

One standing tiff was with the resident of a neighbouring building (distance between plots approximately six meters). As the construction plot was vacant for some years, it had very lush greenery along its northern border. The trees provided ample shade for the residents, so they did not take kindly to the trees being cut down for construction purposes. Since the Japanese government was following a transparent construction procedure, the Public Greenery officials inspect the site and made a 'greenery report'. The developer of the property has the discretionary right to keep or remove the existing greenery. If the decision is the latter, after official inspection and report, the investor is obligated to pay a fee to the city, depending on the age and rarity of vegetation. Those funds will be theoretically used for new planting and greenery maintenance within municipal and city borders.

One of the issues that added to unrealistic expectations, which could have been managed, was the lack of any imagery of the appearance of the completed building. Normally (and regulated by the Serbian Law on Planning and Construction, Article 149), before the start of construction, the investor is obligated to provide information about the new building on the construction board. In this instance, claiming intellectual copyright properties of the $3 \mathrm{D}$ visualization company, there were no officially circulated images of the final embassy building's appearance. Apart from one frontal façade rendering (Image 4), there were no graphic representations, adding to the mystery and expectations.

\section{DISCUSSION}

Still, one must wonder whether the policy-makers of the Government of Japan are aware of the impact SPA can have on public diplomacy. One of the key questions is whether there is any synchronization between the efforts of public diplomacy officials and administrators that approve the design of the building, unaware of the negative consequences it may have on other policy aspects? Or maybe the officials deem it a 'necessary evil' to provide safety to diplomatic staff and avert their efforts onto other channels to mitigate the negative impact of public perception.

An interesting by-product of successfully implemented soft power architecture can be perceived in spatial branding. Comparable to nation branding when done correctly, soft power architecture can bring an added layer of spatial identities to the environments placed. Previously known for its Chinese embassy, the urban identity of New Belgrade's Block 11a has slowly changed to that of the Japanese embassy. It is, however, necessary to underscore that this new place identification is still without any connotation: whether it will develop into positive or negative perception, subsequently influencing spatial (and bilateral) relations, remains yet to be seen. Interestingly, these processes can be, to an extent, influenced by well-thought-out cultural relation policies.

It is important to note that new soft power architectures are a reflection of its time, namely the complex geopolitical situation and international relations. Serbia's geographical location makes it a gateway to Western Europe for China's New Silk Road initiative ${ }^{6}$, so new [architectural] developments can be viewed

6 https://www.ft.com/content/003bad14-f52f-11e6-95ee-f14e55513608 
as calculated. Moreover, recent high-ranking visits, possibly corroborate this claim, as Serbia has received delegations including the President of the PRC, Mr. Xi Jinping (June 2016) and the Japanese Prime Minister, Mr. Shinzo Abe (January 2018).

In conclusion, the previously given hypothesis will be briefly examined and commented, as the majority of inquiries were uncovered during the discussion on each particular segment.

Limited awareness of official governing bodies: largely been confirmed as true. As navigating the global arena of international relations can be taxing, and as soft power architectures are infrequently built, there is no perceived need to explore the issues of exported architecture.

\section{Lack of interdepartmental cooperation of governing}

bodies: presumably true, but claims on its validity cannot be fully ascertained. Additional in-depth research is needed to determine whether the allegations of this hypothesis are true. One can only speculate, based on previous comparable data sets (Kawamura, 2018b), but a full-scale inquiry focusing on the specific processes of realizing soft power architecture is necessitous.

Importance of spatial consequence management, as a linchpin of soft power architecture: Confirmed for the presented case study (spatial consequences, branding, and projected effects onto the urban environment). It is suggested for other case studies to be examined, especially noting soft power architecture buildings with longer life spans. Additionally, developing comparative case studies is recommended, evaluating the spatial consequences of different types of soft power architecture, in varying urban and architectural contexts.

When it comes to the current possibility of integration of diverse professions in culture relation policies for SPA, it is limited but not non-existent. For example, a recent initiative of the Serbian government for construction of the new diplomatic-consular headquarters in Canberra, Australia ${ }^{7}$ was particular in many ways. Firstly, an international ${ }^{8}$ architectural competition was held, obtaining the best design proposals. The design brief, complex in its requirements, had been drafted trough interprofessional cooperation (Serbian Ministry of Foreign Affairs, the Society of Serbian Architects and the City of (anberra). This process can be utilized as an example of good practice: new developments are synchronized with the country's foreign policy goals, with room for refinement, and raising the awareness of policymakers.

7 http://www.u-a-s.rs/konkursi/item/258-republika-srbija-ministarstvospoljnih-poslova-republike-srbije-u-saradnji-sa-udru\% C5\%BEenjemarhitekata-srbije-raspisuje-konkurs-za-dizajn\%E2\% 80\%93-otvoreniprojektni-jednostepeni-anonimni-arhitektonsko-urbanisti\%C4\%8Dki-konkursza-kompleks-ambasade-republike.html

8 Although the official competition language was Serbian, there were no restrictions based on nationality.

\section{CONCLUSION}

The emphasis and challenges in 'new' public diplomacy and subsequently soft power architecture as an extension of that diplomacy, lie in greater emphasis on people-to-people contact, especially given the age of social media; this does not, however, negate the past lesson but rather increases their significance (Cull, 2009).

Furthermore, Cull (ibid.) addresses the notions of 'propaganda' and 'public diplomacy': both are dealing in the sphere of 'influence', but unlike propaganda, public diplomacy is not a one-way street to the intended audience:

At its best, public diplomacy is a two-way street: a process of mutual influence whereby a state (or other international player) facilitates engagement between publics or tunes its own policies to the map of foreign public opinion. In the ideal case, public diplomacy treats the foreign public as an active participant - not just as a flock of sheep waiting to be ideologically shorn.

Active participation is the watchword when it comes to soft power architecture: all actors and parties involved (for both countries) ought to be aware of the delicacy of the issues at stake. However, since this awareness is yet to be built and full extent of exported architectural typologies to be grasped, research remains in the sphere of academia. Similarly, the issues at hand ought to be addressed and all participants educated, as so they can make informed, more responsible decisions, with long-term city developmental strategies in mind.

Similarly, Muratovski (2014), makes an exceedingly important point on the ethical and moral obligations of the architects and urban planners dealing with the issues of soft power architecture at large and their immense responsibility:

Like politicians, designers and architects often use ideologies (self-invented or borrowed) to shape their communicative and creative processes. It is their beliefs and dialogues that condition what ideals may lead to a better society and how these ideals can be put into practice-often for the benefit or to the detriment of the society at large. In most cases these practices are juxtaposed with moral and ethical issues that are too great to be ignored.

The reason professionals, policy researchers, and producers alike should be aware of these issues and push for the more involved approach are proven, tangible long-terms effects cultural relations policies and soft power architecture produce. Although demanding, exploration of these issues ought to be an invitation for cooperation in solving challenges and ensuring sustainable development of cities and bilateral relations, avoiding questionable spatial and diplomatic decisions.

\section{REFERENCES:}

1. Arhi.pro (n.d.). Embassy of Japan. Retrieved from https://www.arhipro.com/en/ references/design/embasy-of-japan

2. Berridge, G. R. (2015). Diplomacy: theory and practice. Basingstoke: Palgrave Macmillan.

3. Blagojević, Lj. (2007). Novi Beograd: osporeni modernizam [New Belgrade: disputed modernism]. Beograd: Zavod za udžbenike. 
4. Butler, C. (2014). Henri Lefebvre: Spatial politics, everyday life and the right to the city. -Abingdon-on-Thames: Routledge-Cavendish.

5. Castells, M. (1977). The urban question: a Marxist approach (Social structure and social change). Cambridge, MA: MIT Press.

6. Cull, J. N. (Ed.) (2009). Public diplomacy: lessons from the past. Retrieved from https:// uscpublicdiplomacy.org/sites/uscpublicdiplomacy.org/files/useruploads/ u35361/2009\%20Paper\%202.pdf

7. Dale, P. (2011). The myth of Japanese uniqueness. New York: Routledge.

8. EU sets collision course with China over 'Silk Road' rail project. (2017, February 19). Retrieved from https://www.ft.com/content/003bad14-f52f-11e6-95eef14e55513608

9. Hristić Danilović, N. (2013). Bezbednost urbanih prostora [Safety of urban public spaces].Belgrade: Orion Art.

10. Ignjatović, A. (2007). Jugoslovenstvo u arhitekturi 1904-1941[Yugoslavian in architecture 1904-1941]. Belgrade:Građevinskaknjiga.

11. Iriye, A. (1997). Cultural internationalism and world order. Baltimore: Johns Hopkins UniversityPress.

12. Izmene i dopune generalnog urbanog plana Beograda 2021-Faza I (2007, October 17). Retrieved from http://sllistbeograd.rs/pdf/2007/34-2007. pdf\#view=Fit\&page $=1$

13. Jovin, B. (2015, March 3). Urbanistički promašaj [Urban planning failure]. Politika

14. Kawamura, Y. (2018a). Beyond cultural diplomacy: the study of international cultural relations (ICR)- a new perspective of cultural policy research in a globalized world. Retrieved from https://researchmap.jp/?action=cv_download_main\&upload_ $\mathrm{id}=175862$

15. Kawamura, Y. (2018b). Experts in cultural policy-making in Japan: two expert networks and the making of the basic act on the promotion of culture and the arts (BAPCA). Bulletin of the Faculty of Humanities Seikei University, 53, 47. Retrieved from http://repository.seikei.ac.jp/dspace/bitstream/10928/1006/1/ bungaku-53_47-62.pdf

16. Kawamura, Y. (2016). Methodological duality and conceptual plurality of culture in international relations: towards collaboration of cultural policy research and international relations. Bulletin of the Faculty of Humanities Seikei University, 51. Retrieved from https://researchmap.jp/?action=cv_download_main\&upload_ id $=132512$

17. Kishida wins funding for six new embassies, two new consulates. (2015, January 12). Retrieved from https://www.japantimes.co.jp/news/2015/01/12/national/ politics-diplomacy/ministers-give-ok-six-new-embassies-two-consulatesopen/\#.XPTwWogzZPY

18. Loeffler, C. J. (2011). The architecture of diplomacy. Building America's embassies. New York: Princeton Architectural Press.

19. Mayo, J. (1996). The manifestation of politics in architectural practice. Journal of Architectural Education, 50(2), 76-88. Retrieved from https://www.jstor.org/ stable/1425358?seq=1\#metadata_info_tab_contents

21. Mingst, K \& Arreguín-Toft, I. (2014). Essentials of international relations, New York:W.W.Norton\& Company.

22. Muratovski, G. (2014).The burden of ethics: the use of design and architecture as political propaganda. Retrieved from http://www.academia.edu/19835843/ The_Burden_of_Ethics_The_Use_of_Design_and_Architecture_as_ Political_Propaganda_Conference_Paper

23. Nye, J. (2004). Soft power: the means to succeed in world politics. Cambridge, MA:PublicAffairs.

24. Radović, D. (2015). Measuring the non-measurable: public-private interface, $M n^{\prime} M$ edition Tokyo. Tokyo: flick Studio and IKI.

25. UNESCO (n.d.). The soft power of culture: questions and answers. Retrieved from http://www.unesco.org/culture/culture-sector-knowledge-managementtools/11_Info\%20Sheet_Soft\%20Power.pdf

26. Union of Architects of Serbia (2018, May 16). Republika Srbija Ministarstvo spoljnih poslova Republike Srbije u saradnji sa Udruženjem arhitekata Srbije raspisuje - konkurs za dizajn- otvoreni projektni, jednostepeni, anonimni arhitektonsko-urbanistički konkurs za kompleks Ambasade Republike [The Ministry of Foreign Affairs of the Republic of Serbia, in cooperation with the Union of Architects of Serbia, announces - design contest - open project, one-stage, anonymous architectural-urban competition for the Embassy of the Republic complex]. Retrieved from http://www.u-a-s.rs/konkursi/ item/258-republika-srbija-ministarstvo-spoljnih-poslova-republike-srbijeu-saradnji-sa-udruženjem-arhitekata-srbije-raspisuje-konkurs-za-dizajn-0tvoreni-projektni-jednostepeni-anonimni-arhitektonsko-urbanistički-konkursza-kompleks-ambasade-republike.html

26. Vasiljevič Tomić D., Nikezić A. \& Ćrić D. (2013). Negotiating cultural identity through the architectural representation case study: foreign embassy in Belgrade. FACTA UNIVERSITATIS Series: Architecture and Civil Engineering, 11(2): 113-124

27. Yoshino, K. (1992). Cultural nationalism in contemporary Japan: a sociological enquiry. London: Routledge.

28. Žižek, S. (Ed.) (1994). Mapping ideology. London: Verso. 